\title{
Technological Innovation in the Pharmaceutical Firms: The Role of Entrepreneurial Orientation and Network Capability
}

\author{
Yan Zhang
}

\begin{abstract}
We know little about the relationship between entrepreneurial orientation(EO) and technological innovation. Moreover, the intermediate mechanisms of how entrepreneurial orientation transfers into technological innovation is not yet clear. This study attempts to integrates the resource-based view, dynamic capability theory and network theory in order to address four questions. Specifically, the entrepreneurial orientation(EO) is considered as a kind of key entrepreneurial-based asset, the network capacity is a kind of critical capability, which enables corporates transferring their entrepreneurial assets into technological innovation. We focus on the mechanism of how entrepreneurial orientation and networking capabilities work to achieve corporates' technological innovation. The first one is what's the impact of entrepreneurial orientation on technological innovation. the second question is what's the impact of network capacity on technological innovation. Third, the moderating effect of network capability on the relationship between entrepreneurial orientation and technological innovation. Fourth, the moderating effect of environmental uncertainty on the main effect relationship. This paper uses an empirical research methods to text our therory model. Finally, our paper has two main contributions, first, it has identified and examined the network capability of enterprises, that enables enterprises to respond to market signals and uncertain environment effectively. Second, the article also identified two moderating variables on the relationship between EO and technological innovation.
\end{abstract}

Index Terms-Entrepreneurial orientation, network capability, technological innovation, pharmaceutical firms.

\section{INTRODUCTION}

On the one hand, trends such as globalization, fast product-cycle times, greater competition, product commoditization and technology fusion, technological innovation has become increasingly critical for firms. Moreover, as the basis of pharmaceutical firm's competitive advantage is successful innovation, many scholars point out that, pharmaceutical firms depend heavily on the success of research results to promote the company's profitability and growth, which reinforces the importance of technological innovation for pharmaceutical companies. Unlike mechanical assembled products industries, the pharmaceutical industry's core product centers on a molecule [1]. Therefore, the pharmaceutical industry as provides us for a good research context to examine the incremental and radical innovation. The technological

Manuscript received December 17, 2016; revised March 5, 2017

Yan Zhang is with the School of Economics and Management, China University of Petroleum, Qingdao 266555 (e-mail: zhangyan2010@zju.edu.cn). innovation is divided into incremental innovation and radical innovation in this paper. Radical innovations represent major changes in technology involving the discovery of new knowledge, substantial technical risk, time, and cost. Incremental innovations represent minor changes to existing technology involving small advances based on an established foundation of knowledge [2].

On the other hand, both of the strategic management [3] and entrepreneurship literature [4] regards the entrepreneurial orientation (EO) as the source of competitive advantage and success of a organizational. Entrepreneurial orientation [5] is an extension of the concept of entrepreneurship from the individual level to the organizational level. It reflects the extent to which a firm is committed to risk-taking, innovation, and proactiveness in developing and implementing its strategies [6].

Entrepreneurial orientation has been considered to be positively related to firm performance because it can help firms to gain from first-mover advantages and seize opportunities [7]. However, some studies don't find this positive correlation between entrepreneurial orientation and performance.

Of the previous research, there are three streams study the relationship between EO and corporate performance, the first stream is on the direct relationship between EO and performance. Such as [4] have shown that as the entrepreneurial orientation has strengthen, the performance of corporate is improved. While [8] found that there is no links between entrepreneurial orientation and corporate profit margins. The second stream focuses on the mediating variables between EO and performance in order to understand the mechanisms of relationships better. Such as [9] and other scholars confirmed the existence of market orientation as a mediating variable. The third stream examines the moderators between EO and firm performance, such as organizational structure, resources, strategies and other variables. [10] confirmed empirically the moderating role of environment and in Sdustry life cycle between entrepreneurial orientation and firm performance.

However, we know little about the relationship between entrepreneurial orientation (EO) and technological innovation. Moreover, the mediating mechanisms of how entrepreneurial orientation transfers into technological innovation is not yet clear. Research on open innovation emphasizes that firms should acquire external resources, technologies and capabilities through inter-firm ties network, because firms have access to network resources does not necessarily automatically transfer into improved technological innovation. Therefore, it is not enough for firms to access to external resources, technologies and 
capabilities during the implementation process of entrepreneurial orientation, firms must develop and manage its external network and activate the network resources in order to use of its external ties network to promote innovation capabilities. Although many scholars have begun to concern about the network capability, most studies are only about the conceptual or statistical correspondence relationship between the network capability and innovation outcomes, despite this issue is very important for the enterprises to achieve technological innovation, the specific influential path between them has received less attention.

Therefore, to fill this research gap, this study attempts to integrates the resource-based view, dynamic capability theory and network theory in order to address four questions. Specifically, the entrepreneurial orientation (EO) is considered as a kind of key entrepreneurial-based asset, the network capacity is a kind of critical capability, which enables corporates transferring their entrepreneurial assets into technological innovation. We focus on the mechanisms of how entrepreneurial orientation and networking capabilities work to achieve corporates' technological innovation. The first one is what's the impact of entrepreneurial orientation on technological innovation. The second one is what's the impact of network capacity on technological innovation. The third question is the moderating effect of network capability on the relationship between entrepreneurial orientation and technological innovation. The fourth one is the moderating effect of environmental uncertainty on the relationship between entrepreneurial orientation and technological innovation.

\section{THEORETICAL BACKGROUND AND HYPOTHESES}

\section{A. Entrepreneurial Orientation and Technological Innovation}

Entrepreneurial orientation captures specifically the entrepreneurial aspects of firms' strategies[11]. Entrepreneurial orientation can be seen as an organizational resources to provide with sustainable competitive advantage for organizations, because it is embedded in the organizational path, invisible, and dispersed among the members in the organization. Innovativeness, proactiveness and risk taking are considered to be the central content of entrepreneurial orientation[6]. Innovativeness encompasses a firm's willingness to embark upon experimentation, to support new ideas, and to favour changes in practice. Proactiveness refers to the tendency to act in terms of anticipating changes in the operating environment, and pioneering new methods, techniques, and products. Risk-taking propensity is associated with the willingness to invest in projects that have uncertain outcomes or unusually high profits or losses. The main proposition of entrepreneurial orientation is that organizations acting entrepreneurially are better able to adjust their operations in dynamic competitive environments. Entrepreneurially oriented organizations change and shape the environment and are willing to commit resources to exploiting uncertain opportunities. They explore new and creative ideas which may lead to changes in the marketplace, and do so proactively ahead of the competition in anticipation of future demand. This kind of better adjustment and shaping of the environment should have positive effects on firm performance [12], [13].

Entrepreneurship improves a firm's overall learning and drives the wide range of knowledge creation that builds and reconfigures the sources of its competitive advantage. Empirical results suggest that corporate entrepreneurship improves firm performance by increasing the company's proactiveness and risk taking, and by promoting product, process, and service innovations.

A proactive firm is a leader rather than a follower, given its willingness and foresight to seize new opportunities [14]. First mover advantages are emphasized as the best strategy for capitalizing on a market opportunity. Usually, first movers can capture high profits and are able to establish a corporate reputation as a technological leader. Achieving competencies in the latest product technologies and the development of advanced production processes may lead to a superior market performance. Setting ambitious market-goals, doing things differently, and redefining products and services are considered to be effective means to pursue competitors. Therefore, we propose the following hypothesis:

H1a: Entrepreneurial orientation positively affects drug enhancement innovation

H1b: Entrepreneurial orientation positively affects new drug innovation

\section{B. Network Capability and Technological Innovation}

The network capability construct is based on the contributions to "alliance capability" [15], "relational capability" [16]. Lorenzo and Lipparini (1999) considered network capability as a kind of relational capabilities, namely the ability to interact with other companies which is based on absorption, joint and coordinated capabilities. Based on that, [17] extended the definition of network capacity, they believe that the network capability is not just a type of relational capability among enterprises, but is the capability of developing and using of inter-firm relationships. [18] extended the definition of network capability, they regarded the network capability as the enterprises' ability to build, maintain and use the relationship with various external network partners.

Möller and Halinen (1999) began to focus on the dimensions of network capability very earlier, the network capability was divided into network vision capabilities, network management capabilities, portfolio management capabilities and relationship management capabilities. [18] believed that the network capability including four parts, they are relational skills, coordination activities, partner knowledge and internal communication. In this study, we followed the view of [18].

Coordination between collaboration firms has been highlighted in many dyadic studies [19], while cross-relational coordination has also been suggested. Coordination activities are boundary-spanning activities connecting the firm to other firms and connecting different individual relationships into a network of mutually supportive interactions. Relational skills, also referred to avoid or handle instabilities in their partnerships [20]. Partner knowledge allows for situation-specific management with a partner, such as the reduction of transaction control 
costs, and a proactive and solution oriented conflict management. Overall, partner knowledge stabilizes a firm's position where necessary within a network. Internal communication is also included in the concept of network capability. Studies on market orientation have always confirmed that internal communication is essential for being responsive and open[21], and for effective organizational learning within partnerships. From a relational perspective, [22] also point to internal communication as an integrated part of collaborative competence. Assimilating and disseminating up-to-date information on partners, their resources and agreements with them to all involved departments help to avoid redundant process and miscommunication as well as improve the detection of synergies between partners [23].

The improvement of the network capability enables firms to hold a more benefit position in the network, strengthen the communication and interaction among various organizations in different fields, to obtain the rare resources from the network in order to enhance the innovative capability and performance of firms [24]. Each pharmaceutical firm which is oriented in technological innovation is within a natural network, their R\&D activities including labs build jointly, products develop jointly and ventures build could be influenced by the degree of technological innovation of other participants in the firms network. The pharmaceutical firms which have been developed into a certain level or certain stage, their various resources and internal capabilities have been utilized sufficiently, they probably don't have more resources and capabilities to acquire innovative drug projects, therefore that hinder the firms' technological innovation(including drug enhancement innovation and new drug innovation). Close relationships provide entrepreneurs and their organizations with avenues for negotiation and persuasion, enabling them to gather a variety of resources (e.g., market information, ideas, problem solving, social support, venture funding, and financial resources) held by other actors [25], [26].

Cooperation enables firms to acquire resources of heterogeneity more faster, especially the knowledge and technologies that spans the local boundary and the the knowledge and technologies from the foreign partners. At the same time, firms could develop and strength themselves through utilizing and integrating the relational network, resources and technologies which are shared with partners. Especially, pharmaceutical firms could obtain accurate information on the market, technology and management and to eliminate the uncertainty of information they have obtained through maintaining the close relationships with those partners that have higher position.

Moreover, pharmaceutical firms could also acquire various types of knowledge through organizational learning, especially the knowledge and technologies on drug enhancement $R \& D$ and new drug $R \& D$, and then transfer them into $R \& D$ capabilities and technological innovation within the firms. All of this collaboration is depended on network capability of enterprises. The increasing of various elements of the network capability could enhance the overall network capability, and then bring in a good performance on $\mathrm{R} \& \mathrm{D}$ activities and technological innovation performance is improved.
H2a: Network capability positively affects drug enhancement innovation

H2b: Network capability positively affects new drug innovation

\section{Moderating Effect of Network Capability}

Entrepreneurial orientation is a kind of organizational resources which provide sustainable competitive advantage for organizations, because it is embedded in the organizational path and dispersed among the members in the organization. However, the research on entrepreneurial orientation shows that, newly created pharmaceutical companies are often unable to successfully transfer the entrepreneurial orientation into higher performance and technological innovation due to its lack of strategic capability [27]. However, the network capability of the enterprise is a kind of strategic capability. Thus, the entrepreneurial oriented enterprises could promote their value creation only when they can strategically acquire, develop and exploit resources which can nature the search behavior of firms [28].

Network capability is conceptualized as a firm-level conceptthat affects a broad array of activities within an organization and across its boundaries and, therefore, has the potential to moderate the contribution of entrepreneurial orientation to technological innovation [15]. We assume that $\mathrm{NC}$ advances the effectiveness and efficiency of entrepreneurial orientation. Activities and resources that constitute a firm's NC can be seen as contextual factors that may enhance strategic assets and facilitate processes that enable the firm to behave proactively and innovatively in a more effective way [29]. A network capable firm will be more likely to attain superior technological innovation based on new products and services, as it continually monitors customer preferences and competitor actions, disseminating this information throughout the organization and within the supplier network. Networking firms are better able to anticipate new preferences, are aware of competitors' actions quickly, and can either develop new market offerings when competitor copying becomes apparent or can imitate their innovations. Furthermore, internal communication and social competencies that foster an adequate implementation climate[30], like empathy and conflict management skills, are also useful for successful completion of internal innovation processes. Highly entrepreneurial-minded firms, like prospectors, are innovative risk takers striving aggressively for competitive advantages and growth. Growth mainly comes from development of new markets, expansion of product and service offerings, and customer satisfaction. Therefore, EO should lead to better performance when the firm concentrates on customer (latent) needs and employs mechanisms for adaptation, knowledge transfer, and relationship development. Stated formally:

H3a: Network capability strengthens the effects of entrepreneurial orientation on drug enhancement innovation

H3b: Network capability strengthens the effects of entrepreneurial orientation on new drug innovation

\section{Moderating Effect of Environmental Uncertainty}

Environmental factors as important contingency variables have been widely acknowledged in the literature. 
Environmental uncertainty refers to the degree of change and unpredictability of a market environment [6]. In uncertain environments, although managers have great difficulties in getting access to the information they need, and they have difficulties in understanding, believing, and acting upon information collected. [31] considered that in highly uncertain environments, bases for competitive advantage, industry structure, and product performance standards are generally short lived or in a constant state of flux. Thus, pharmaceutical enterprises can achieve product market superiority through competitive aggressiveness which distances from their industry rivals.

The effect of entrepreneurial orientation on technological innovation may be more explicit under the situation of environmental uncertainty. For example, the rapid technological change can significantly reduce the life cycle of existing products [32], firms must strengthen their R\&D intensity and seize new technical opportunities which enable the firms to launch the products of next generation. Highly uncertainty period in the environment, companies need to interact actively with the user, and thus more proactively to anticipate, identify the needs of users and to seek improved drug or a more efficient molecular compounds. Therefore, we propose hypothesis.

H4a: Environmental uncertainty will moderate the relationship between entrepreneurial orientation and drug enhancement innovation: in a highly uncertain environment, firms with high entrepreneurial orientation will have higher drug enhancement innovation

H4b: Environmental uncertainty will moderate the relationship between entrepreneurial orientation and new drug innovation: in a highly uncertain environment, firms with high entrepreneurial orientation will have higher new drug innovation

\section{E. Conceptual Model}

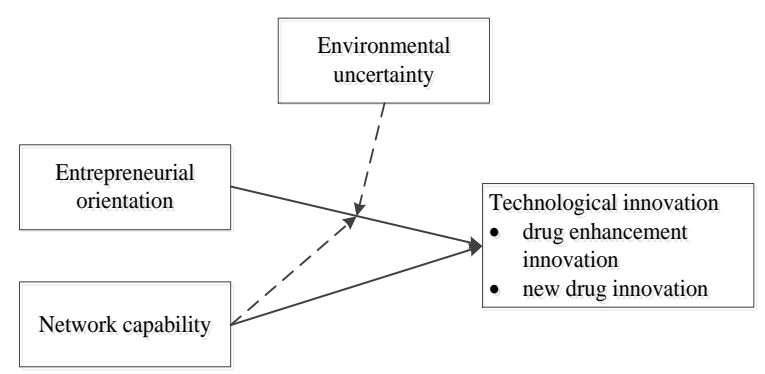

Fig. 1. The Conceptual model of this study.

\section{DISCUSSION}

This study examines how NC and EO affect the technological innovation of pharmaceutical firms in China. We have identified two moderating variables, specifically, the moderating effect of $\mathrm{NC}$ on the relationship between $\mathrm{EO}$ and technological innovation, and the moderating effect of environmental uncertainty on the relationship between EO and technological innovation. These results support the general notion that the EO-performance relationship depends on the context in which it occurs. For these reasons, entrepreneurial activities should not be regarded as panacea for improving organizational performance [33].

This study has two main contributions. First, it has identified and examined the network capability of enterprises, that enables enterprises to respond to market signals and uncertain environment effectively. Our result has provided new insight for the relationship between entrepreneurial orientation and technological innovation, we consider that entrepreneurial orientation requires a network capabilities in order to achieve complementarity. Second, the article also identified two moderating variables on the relationship between EO and technological innovation.

This study has important implications for the management of pharmaceutical firms. Firms should note that an entrepreneurial orientation in and of itself is not enough to compete in today's markets. Entrepreneurial ambitions alone do not create value and should not be seen as the fundamental force for growth and innovation performance of firms. We suggest that pharmaceutical firms should develop their network capability and their networks as a means to improve innovation performance.

\section{ACKNOWLEDGMENT}

This study is supported by the Shandong Provincial Natural Science Foundation (BS2015YY006), The Humanities and Social Sciences Research Project of Shandong Province(J16WF35)and Annual Qingdao Social Science Planning Research Project (QDSKL160501).

\section{REFERENCES}

[1] R. Henderson and I. Cockburn, "Measuring competence? Exploring firm effects in pharmaceutical research," Strategic Managemen Journal, vol. 15, no. S1, pp. 63-84, 1994.

[2] P. Roussel, K. Saad, and T. Erickson, Third generation $R \& D$ : Managing the Link to Corporate Strategy, Boston, Mass: Harvard Business School Press, 1991.

[3] C. B. Dobni and G. Luffman, "Determining the scope and impact of market orientation profiles on strategy implementation and performance," Strategic Management Journal, vol. 24, no. 6, pp. 577-585, 2003.

[4] J. Wiklund and D. Shepherd, "Entrepreneurial orientation and small business performance: a configurational approach," Journal of Business Venturing, vol. 20, no. 1, pp. 71-91, 2005.

[5] G. T. Lumpkin and G. G. Dess, "Clarifying the Entrepreneurial Orientation Construct and Linking It to Performance," The Academy of Management Review, vol. 21, no. 1, pp. 135-172, 1996.

[6] D. Miller, "The correlates of entrepreneurship in three types of firms," Management Science, vol. 29, no. 7, pp. 770-791, 1983.

[7] S. A. Zahra and J. G. Covin, "Contextual influences on the corporate entrepreneurship-performance relationship: A longitudinal analysis," Journal of Business Venturing, vol. 10, no. 1, pp. 43-58, 1995.

[8] S. F. Slater and J. C. Narver, "The positive effect of a market orientation on business profitability: A balanced replication," Journal of Business Research, vol. 48, no. 1, pp. 69-73, 2000.

[9] K. Matsuno, J. T. Mentzer, and A. Özsomer, "The effects of entrepreneurial proclivity and market orientation on business performance," Journal of Marketing, vol. 66, no. 3, pp. 18-32, 2002.

[10] G. T. Lumpkin and G. G. Dess, "Linking two dimensions of entrepreneurial orientation to firm performance: The moderating role of environment and industry life cycle," Journal of Business Venturing, vol. 16, no. 5, pp. 429-451, 2001.

[11] S. N. Bhuian, B. Menguc, and S. J. Bell, "Just entrepreneurial enough: the moderating effect of entrepreneurship on the relationship between market orientation and performance," Journal of Business Research, vol. 58, no. 1, pp. 9-17, 2005.

[12] G. T. M. Hult, R. F. Hurley, and G. A. Knight, "Innovativeness: Its antecedents and impact on business performance," Industrial Marketing Management, vol. 33, no. 5, pp. 429-438, 2004.

[13] H. T. Keh, T. T. M. Nguyen, and H. P. Ng, "The effects of entrepreneurial orientation and marketing information on the performance of SMEs," Journal of Business Venturing, vol. 22, no. 4, pp. 592-611, 2007.

[14] J. G. Covin and D. P. Slevin, "New venture strategic posture, structure, and performance: An industry life cycle analysis," Journal of Business Venturing, vol. 5, no. 2, pp. 123-135, 1990. 
[15] P. Kale, J. H. Dyer, and H. Singh, "Alliance capability, stock market response, and long-term alliance success: the role of the alliance function," Strategic Management Journal, vol. 23, no. 8, pp. 747-767, 2002.

[16] G. Lorenzoni and A. Lipparini, "The leveraging of interfirm relationships as a distinctive organizational capability: a longitudinal study," Strategic Management Journal, vol. 20, no. 4, pp. 317-338, 1999.

[17] T. Ritter and H. G. Gemünden, "Network competence: Its impact on innovation success and its antecedents," Journal of Business Research vol. 56, no. 9, pp. 745-755, 2003.

[18] G. Human and P. Naude, "Exploring the relationship between network competence, network capability, and firm performance: A resource based perspective in an emerging economy," Management Dynamics, vol.18, no. 1, pp. 2-14, 2009.

[19] J. Mohr and R. Spekman, "Characteristics of partnership success: Partnership attributes, communication behavior, and conflict resolution techniques," Strategic Management Journal, vol. 15, no. 2, pp. 135-152, 1994.

[20] T. K. Das and B. S. Teng, "Instabilities of strategic alliances: An internal tensions perspective," Organization Science, vol. 11, no. 1, pp.77-101, 2000

[21] J. C. Narver and S. F. Slater, "The Effect of a Market Orientation on Business Profitability," Journal of Marketing, vol. 54, no. 4, pp. 20-35, 1990.

[22] E. Sivadas and F. R. Dwyer, "An examination of organizational factors influencing new product success in internal and alliance-based processes," Journal of Marketing, vol. 64, no. 1, pp. 31-49, 2000.

[23] W. M. Cohen and D. A. Levinthal, "Absorptive capacity: A new perspective on learning and innovation," Administrative Science Quarterly, vol. 35, no. 1, pp. 128-152, 1990.

[24] T. Ritter and H. G. Gemünden, "The impact of a company's business strategy on its technological competence, network competence and innovation success," Journal of Business Research, vol. 57, no. 5, pp. $548-556,2004$

[25] H. Hoang and B. Antoncic, "Network-based research in entrepreneurship: A critical review," Journal of Business Venturing, vol. 18 , no. 2 , pp. $165-187,2003$.
[26] N. Nicolaou and S. Birley, "Social networks in organizational emergence: The University spinout phenomenon," Management Science, vol. 49, no. 12, pp. 1702-1725, 2003

[27] M. A. Hitt, R. D. Ireland, S. M. Camp, and D. L. Sexton, "Strategic entrepreneurship: entrepreneurial strategies for wealth creation," Strategic Management Journal, vol. 22, no. 6-7, pp. 479-491, 2001.

[28] R. D. Ireland, M. A. Hitt, and D. G. Sirmon, "A Model of strategic entrepreneurship: The Construct and its dimensions," Journal of Management, vol. 29, no. 6, pp. 963-989, 2003.

[29] Covin and Slevin, "A conceptual model of entrepreneurship as firm behavior," Entrepreneurship Theory and Practice, 1991.

[30] K. J. Klein and J. S. Sorra, "The challenge of innovation implementation," Academy of Management Review, vol. 21, no. 4, pp. 1055-1080, 1996.

[31] H. Li, Y. Zhang, and T. -S. Chan, "Entrepreneurial strategy making and performance in China's new technology ventures-the contingency effect of environments and firm competences," The Journal of High Technology Management Research, vol. 16, no. 1, pp. 37-57, 2005.

[32] T. Li and R. J. Calantone, "The impact of market knowledge competence on new product advantage: Conceptualization and empirical examination," Journal of Marketing, vol. 62, no. 4, pp. $13-29,1998$

[33] J. G. Covin and D. P. Slevin, "The influence of organization structure on the utility of an entrepreneurial top management style," Journal of Management Studies, vol. 25, no. 3, pp. 217-234, 1988.

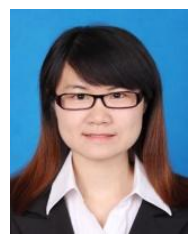

Yan Zhang is an assistant professor of School of Economics and Management, China University of Petroleum, Qingdao 266555, P.R. China.

Her academic domain focuses on strategic management and innovation management. She has graduated from Zhejiang University, School of Management, Ph.D. In the past five years, she has been engaged in the research on R\&D cooperation network and innovation of pharmaceutical manufacturing enterprises. Also, she has published a series of research results, such as 6 articles of CSSCI, seven articles of EI and ISTP and so on. 